\title{
Phytochemical Analysis and Antimicrobial Effect of Chrysophillum Albidum Leave Extract On Gastrointestinal Tract Pathogenic Bacteria and Fungi in Human
}

\author{
Ajetunmobi Asibiallau Oladipupo, Towolawi Gafar Abiodun \\ Lagos State Polytechnic Ikorodu, Lagos State.
}

\begin{abstract}
The procedure described by Adebayo et al., (2010b) was adopted. Fresh leave of Chrysophyllum albidum was rinsed with distilled water to remove dust and other contaminant then air-dried in the laboratory for 14 days. The dried leave was subsequently mashed into fine powder using morta and pestle. The powder was weighed on weighing balance and recorded. $200 \mathrm{~g}$ of C. albidum powder was weighed and transfer into conical flask of $1000 \mathrm{ml} .250 \mathrm{~cm}^{3}$ of methanol was added to the measured powder in the conical flask gently swirled and placed on the table for 5 days. This was later filtered using Muslim clothes and cotton wool in a clean conical flask. The residue was weighed and recorded as well as the substrate. The substrate i.e. the extract was then evaporated using rotary evaporator at $50^{\circ} \mathrm{C}$. The extract was further evaporated with the use of water bath at $48^{\circ} \mathrm{C}$. The resultant extract was weighed and recorded accordingly. The same procedure was repeated using distilled water only that the substrate was not evaporated neither by rotary evaporator nor by water bath. A serial dilution of the two extracts was carried out in separate test-tubes. Results of antimicrobial activity show the activities of the plant extract as a broad spectrum since the Gram-positive and Gram-negative bacteria tested was sensitive to the extracts. The zones of inhibition obtained in respect of the extracts showed that organisms resistant to Ciprofloxacin were susceptible to the extracts. The methanol extracts had highest antimicrobial activities than that of water extracts. The methanol extract have pronounced activity on Candida albicans whereas it did not have any effect on Salmonella species.
\end{abstract}

Key: MIC: Minimum Inhibitory Concentration, MBC: Minimum Bactericidal Concentration, R: Resistant, (+): Sensitive/ Presence (++): More Sensitive (+++): Most Sensitive, (-): Absent

\section{Introduction}

Chrysophyllum albidum also known as African star apple or Agbalumo in Yoruba belongs to the family Sapotaceae with different species. It is primarily a forest tree species that naturally occur in diverse ecozones in Nigeria, Uganda and Niger Republic (Bada, 1997). In Nigeria, it is known by several local names and is generally regarded as a plant with diverse ethno medicinal uses (Amusa et al., 2003). Nigerians have been using C. albidum leaves for series of infection in years back when scientific evidence for its antimicrobial effect was not detected. Studies have been carried out on the seed, Leaves, bark as well as its fruit and root that show the antimicrobial effectiveness on different ailments. For example, the fruit of Chrysophyllum albidum has been found to have a very high content of ascorbic acid with 1000 to 3,300mg of ascorbic acid per $100 \mathrm{~g}$ of edible fruit or about 100 times that of oranges and 10 times that of guava or cashew (Amusa et al, 2003). It was also reported as an excellent source of vitamins, irons, flavours to diet (Adisa, 2000). The fruit are not usually harvested from the trees but left to drop naturally to the forest floor where they were picked up (Amusa et al., 2003). The bark is used as a remedy for yellow fever and malaria while the leaves are used as emollients and for the treatment of skin eruption, diarrhea and stomach ache (Adisa, 2000). Eleagnine, an alkaloid isolated from $C$. albidum seed cotyledon has been reported to have antinociceptive, anti-inflammatory and antioxidant activities (Idowu et al, 2006).

In spite of the rich component and vast local use of Chrysophyllum albidum bark, there is dearth of information on its' effect on antimicrobial activities. In this study, we report the antimicrobial effect of gastrointestinal tracts pathogenic bacteria that causes diseases in human using the extract from the leave of $C$. albidum as part of our exploration for new and novel bioactive compounds.

Antimicrobial agents have been used for over 40 years (Zhanel et al, 1991). The studies of medicinal plants used in folklore remedies have attracted the attention of many scientists in finding solutions to the problems of multiple resistances to the existing synthetic antibiotics. Most of the synthetic antibiotics now available in the market have major setback due to the multiple resistance developed by pathogenic micro-organisms against these drugs (Akinpelu et al, 2008).

Presently the emergence of immuno-compromised cases and new strains of disease causing bacteria require that antibiotics are closely monitored (Kirby and Craig, 1981; Kunin, 1981). 


\section{Collection and Identification of Plant}

The fresh leaves of Chrysophyllum albidum were collected from its natural habitat Ijede in Ikorodu area of Lagos State, Nigeria. It was collected in the month of March, 2013. The leaves were disinfected and dried at room temperature for 2 weeks and then grounded to powder.

\section{Preparation of Leave extracts with Distilled Water}

$200 \mathrm{~g}$ of the powdered leave of C. albidum was dissolved in $1000 \mathrm{ml}$ of distilled water and allowed to soak for 48 hours after which the filtrate was collected and the residue was spread and dried. The substrate was then serially diluted in 10 test-tubes.

\section{Preparation of Leave extracts with Methanol}

$250 \mathrm{~cm}^{3}$ of $70 \%$ methanol was added to $200 \mathrm{~g}$ of powdered leave and soaked for 72 hours, after which the whole mixture was filtered; the filtrate was labeled methanol fraction. The mixture was filtered with Whatman's filter paper.

The methanol fraction was evaporated to dryness in-vacuo. The extracts were stored at $4{ }^{\circ} \mathrm{C}$ until use. The serial dilution was as well carried out using 10 test-tubes.

\section{Organisms}

The microorganisms used in this study consisted of one yeast, 2 Gram -positive, and 2 Gram negative bacteria. They are Staphylococcus aureus, Escherichia coli, Candida albicans, Salmonella typhi, and Corynebacterium.

\section{Media}

Nutrient broth, Sensitivity test agar, Tryptone soy agar and Mc conkey agar all products of Oxoid Laboratories in England were used in this study. They were prepared according to the manufacturer's instructions.

\section{Antimicrobial Agents}

The chemotherapeutic agents used in the test as positive control were Ciprofloxacin $10 \mu \mathrm{g} / \mathrm{ml}$ (Nicholas Laboratories Limited, England) and streptomycin.

\section{Phytochemical Analysis of the Plant Extract}

The quantitative chemical analysis of the plant sample was carried out for the presence of anthraquinones, tannins, saponnins, steroids, cardiac glycosides, flavonoids, terpenoids and alkaloids using the method adopted in similar surveys [Mbatchou et al. (2010)]

Test for Tannins: A small quantity of the extract was mixed with distilled water and heated on a water bath. The mixture was filtered and ferric chloride was added to the filtrate. A blue solution indicated the absence of tannins in distilled water and dark green colour indicating presence in methanol.

Test for Saponins: About $0.2 \mathrm{~g}$ of plant extract was mixed with distilled water and heated to boil. Frothing (appearance of creamy mix of small bubbles) showed the presence of Saponins in Methanol while red in Distilled water.

Test for Terpenoids: The extract $(0.2 \mathrm{~g})$ was mixed with $2 \mathrm{ml}$ of chloroform, and $3 \mathrm{ml}$ of concentrated $\mathrm{H}_{2} \mathrm{SO}_{4}$ was carefully added to form a layer. A reddish brown interface was formed which indicated the presence of terpenoids on both extract.

Test for Steroids: Acetic anhydride $(2 \mathrm{ml})$ was added to $0.5 \mathrm{~g}$ of the extract in a test tube. It was then followed by the addition of $2 \mathrm{ml}$ of sulfuric acid. A colour change from violet to blue or green indicated the presence of steroids on both extract.

Test for Flavonoids: About $0.2 \mathrm{~g}$ of the extract was dissolved in dilute sodium hydroxide solution, and equal amount of hydrochloric acid was added. A yellow solution that turned colourless indicated the presence of flavonoids on both extract.

Test for Alkaloids: The aqueous extract $(3 \mathrm{ml})$ was stirred with $3 \mathrm{ml}$ of $1 \% \mathrm{HCl}$ on a steam bath. Mayer's reagent was then added to the mixture. Turbidity of the resulting precipitate was taken as positive evidence of alkaloids on both extract. 
Test for Anthraquinones: About $0.5 \mathrm{~g}$ of the extract was boiled with $2 \mathrm{ml}$ of $10 \% \mathrm{HCl}$ for few minutes in a water bath. The resultant solution was filtered and allowed to cool. Equal volume of chloroform was added to the filtrate. Few drops of $10 \% \mathrm{NH}_{3}$ solution was added to the mixture and heated. Formation of rose pink colour indicated the presence of anthraquinones on both extract.

Test for Cardiac glycosides: A small amount of the extract was hydrolyzed in $2 \mathrm{ml}$ of $\mathrm{HCl}$ solution, and neutralized with equal amount of sodium hydroxide solution. Few drops of Fehling's solution A and B were added. Red precipitates indicated the presence of glycosides on both extract.

\section{Determination of Antimicrobial Activity \\ Culture Methods}

Overnight culture of the test organisms was prepared by sub-culturing the organisms from stock cultures into sterile nutrient broth in tubes. The tubes were incubated at $37^{\circ} \mathrm{C}$. A $1: 100\left(10^{-2}\right)$ dilution of each culture was prepared and used for the study.

\section{Antimicrobial Screening of Plant Extracts}

This was carried out using the agar cup diffusion technique described by Hugo and Russel (1998 and Adeniyi et. al, 1996). $1 \mathrm{ml}$ of a 1:100 dilution of an overnight culture of each bacterial isolates was used to seed sterile molten sensitivity test agar medium maintained at $45^{\circ} \mathrm{C}$ while Mc conkey agar was carpeted with the same volume of the bacterial. The plates were incubated at $37^{\circ} \mathrm{C}$ for 24 hours. A standard cork borer of $8 \mathrm{~mm}$ diameter was used to cut equidistant wells on the surface of the agar into which was added $0.1 \mathrm{ml}$ solution of each extracts reconstituted with $100 \%$ ethylacetate to final concentrations of $1 \mathrm{mg} / \mathrm{ml}, 2 \mathrm{mg} / \mathrm{ml}, 10 \mathrm{mg} / \mathrm{ml}$ and $20 \mathrm{mg} / \mathrm{ml}$. The plates were incubated at $37^{\circ} \mathrm{C}$ for 24 hours after which diameters of zones of inhibition were measured. $100 \%$ ethylacetate was included in each plate as a solvent control while Ciprofloxacin $(10 \mu \mathrm{g} / \mathrm{mL}) \mathrm{and}$ Streptomycin were used as positive control respectively.

\section{Determination of Minimum Inhibitory Concentration (MIC)}

The MIC for the bioactive methanol extracts was determined by the agar dilution method (Russel and Furr, 1977, Lajubutu, et. al, 1995). Different concentrations of the extracts were prepared to final concentration in the range of $20 \mathrm{mg} / \mathrm{ml}$ to $0.5 \mathrm{mg} / \mathrm{ml}$. Two milliliters $(2 \mathrm{mls})$ of the extract from each dilution was mixed with $18 \mathrm{mls}$ of molten sensitivity test agar and poured into sterile Petri dishes allowing the agar to set. The surface of the agar was allowed to dry before streaking with overnight broth cultures of test organisms. The plates were incubated accordingly after which the lowest concentration preventing visible growth was Chrysophyllum albidum leave extracts (methanol fraction) taken as the Minimum Inhibitory Concentration (MIC) of the extract. The procedure was repeated for the water extract.

\section{Determination of Minimum Bactericidal Concentration (MBC)}

The MBC for the bioactive extract was determined using methods described by Olorundare et al, 1992. Concentrations higher than and equivalent to the MIC were prepared in broth, $0.5 \mathrm{mls}$ of a 24 -hr culture of test organisms were added to $4.5 \mathrm{mls}$ of the extracts solution in test tube. The mixture was incubated at $37^{\circ} \mathrm{C}$ for $4 \mathrm{hr}$ after which aliquots of samples were withdrawn. Ten-fold dilutions were made and $0.2 \mathrm{mls}$ of $10^{-3}$ dilution was transferred into extract-free sterile sensitivity test agar in Petri dish. The agar plates were incubated at $37^{\circ} \mathrm{C}$ for 24 hours and observed for absence or presence of growth. The minimum concentration preventing visible growth of the organisms was taken as MBC. The procedure was performed for water extract as well.

TABLE 1.0 Phytochemical Analysis of the Plant Extract using Distilled water

\begin{tabular}{|l|c|}
\hline PARAMETERS & $\begin{array}{c}\text { Leave Extract (Distilled } \\
\text { Water) }\end{array}$ \\
\hline Alkaloids & + \\
\hline Tannin & - \\
\hline Cardiac glycoside & + \\
\hline Anthraquinones & + \\
\hline Saponin & - \\
\hline Flavonoids & + \\
\hline Terpenoids & + \\
\hline Steroids & + \\
\hline
\end{tabular}


TABLE 1.1 Phytochemical Analysis of the Plant Extract using Methanol

\begin{tabular}{|l|c|}
\hline PARAMETERS & Leave Extract (Methanol) \\
\hline Alkaloids & + \\
\hline Tannin & + \\
\hline Cardiac glycoside & + \\
\hline Anthraquinones & + \\
\hline Saponin & + \\
\hline Flavonoids & + \\
\hline Terpenoids & + \\
\hline Steroids & + \\
\hline
\end{tabular}

TABLE 2.0 Antimicrobial Screening of Plant Extracts

\begin{tabular}{|l|c|}
\hline TEST ORGANISM & $\begin{array}{c}\text { Leave Extract Distilled } \mathbf{H}_{\mathbf{2}} \mathbf{O} \\
(\mathbf{m g} / \mathbf{m l})\end{array}$ \\
\hline Staphylococcus aureus & 37 \\
\hline Eschericia coli & 42 \\
\hline Salmonella typhi & 45 \\
\hline Corynebacterium & 42 \\
\hline Candida albicans & 40 \\
\hline
\end{tabular}

TABLE 2.1 Antimicrobial Screening of Plant Extracts

\begin{tabular}{|l|c|}
\hline TEST ORGANISM & Leave Extract Methanol (mg/ml) \\
\hline Staphylococcus aureus & 41 \\
\hline Eschericia coli & 45 \\
\hline Salmonella typhi & 45 \\
\hline Corynebacterium & 43 \\
\hline Candida albicans & 41 \\
\hline
\end{tabular}

Table 3.0 Sensitivity Screening for Methanol Extract

\begin{tabular}{|l|l|l|}
\hline Organism & \multicolumn{2}{|c|}{ Antibiotics } \\
\hline Staph. Aureus & Cipro. & Strept. \\
& +++ & +++ \\
\hline E. coli & +++ & +++ \\
\hline Salm. typhi & ++ & +++ \\
\hline Coryn. & +++ & ++ \\
\hline Candida albicans & + & $\mathrm{R}$ \\
\hline
\end{tabular}

Table 3.1 Sensitivity Screening for Water Extract

\begin{tabular}{|l|l|l|}
\hline Organism & \multicolumn{2}{|c|}{ Antibiotics } \\
\hline & Cipro. & Strept. \\
\hline Staph. Aureus & + & ++ \\
& & \\
\hline E. coli & + & $\mathrm{R}$ \\
\hline Salm. typhi & ++ & ++ \\
\hline Coryn. & + & $\mathrm{R}$ \\
\hline Candida albicans & + & $\mathrm{R}$ \\
\hline
\end{tabular}

\section{Results And Discussion}

Phytochemical screening (Table 1.0 and 1.1) showed that the constituents found in the leaves are tannins, flavonoids, saponins, alkaloids anthraquinone, steroids, tarpenoids and cardenolides. These Phytochemical constituents are also in varying degrees. The two extracts obtained were found to possess different degrees of antimicrobial activities.

Results of antimicrobial activity are shown in Table2, the activities of the plant extract appeared to be broad spectrum since the Gram - positive and Gram - negative bacteria tested was sensitive to the extracts. The zones of inhibition obtained in respect of the extracts showed that organisms resistant to Ciprofloxacin were susceptible to the extracts while majority of those that were resistant to streptomycin were also resistant to the extract; only Corynebacterium that has a partial susceptibility on the extracts than others. The methanol extracts had highest antimicrobial activities than that of water extracts. The methanol extract have pronounced activity on Candida albicans whereas it did not have a remarkable effect on others. Some of these bacteria have been implicated in diseases such as diarrhoea, oral and dental infections, respiratory tract infections, urinary tract infections, wound sepsis and dysentery while C. albicans has been implicated in serious infections of mucous membrane and skin thrush, vaginal thrush, acute atrophic candidosis, Adewoye, E.O, Salami, A.T, Lawal, T.O and Adeniyi, B.A chronic atrophic candidosis [Hugo and Russel, 1983; Sleigh and Timbury, 1981]. The strong antimicrobial activities demonstrated by the crude extracts of this plant may therefore justify some of the ethno - 
pharmacological claims about this plant in the treatment of diseases like dysentery, wound, sepsis and cough. Thus further studies on this extract to produce antimicrobial drug of natural source will go a long way in healthcare delivery. The antimicrobial properties exhibited by these plant parts could be traced to the presence of tannins, flavonoids, saponins, alkaloids and most especially anthraquinones.

These phytochemical compounds are biologically active and thus aid the antimicrobial activities of $C$. albidum. Phytochemicals exert antimicrobial activity through different mechanisms; tannins for example, act by iron deprivation, hydrogen bonding or specific interactions with vital proteins such as enzymes (Scalbert, 1991) in microbial cells. Herbs that have tannins as their component are astringent in nature and are used for treating intestinal disorders such as diarrhoea and dysentery (Dharmananda, 2003) thus exhibiting antimicrobial activity. Li et al. (2003) reviewed the biological activities of tannins and observed that tannins have remarkable activity in cancer prevention and anticancer, thus suggesting that $C$. albidum could be a possible source of important bioactive molecules for the treatment and prevention of cancer. In addition to its antimicrobial, anticancer activities, tannins function as stable and potent antioxidants (Trease and Evans, 1983). Alkaloid is also one of the phytochemical compounds observed in the leave extract of $C$. albidum. Alkaloids have been associated with medicinal uses for centuries. One of the most common biological properties of alkaloids is their toxicity against cells of foreign organisms.

Alkaloids possess anti-inflammatory, anti-asthmatic, and anti- anaphylactic properties with consequences of altered immunological status in vivo (Ganguly and Sainis, 2001; Gopalakrishnan et al., 1979; Staerk et al, 2002). Furthermore, alkaloid which is one of the largest groups of phytochemicals in plants has been utilized in the development of powerful analgesics (Raffauf, 1996). It is also a known active compound of most anti-malarial drugs.

Saponins which have been ascertained to be responsible for numerous pharmacological properties (Estrada et al., 2000) were also present in C. albidum leave extract. Saponins are considered a key ingredient in traditional Chinese medicine and are responsible for most of the observed biological effects in medicinal plants (Liu and Henkel, 2002). It has also been reported to produce inhibitory effect on inflammation (Just et al., 1998). It is not unlikely that these bioactive compounds found in C. albidum are the reason for the wide antimicrobial activity exhibited by $C$. albidum.

\section{References}

[1]. Adewoye, EO, Elsie O. Adewoye, Salami, AT, Lawal, TO and Adeniyi, BA,. The Antimicrobial and Kill Kinetics of Chrysophyllum Albidum Stem Bark Extracts. In: European Journal of Scientific Research ISSN 1450-216X Vol.56 No.3 (2011), pp.434-444

[2]. Adewusi HA., 1997. The African Star Apple Chrysophyllum albidum Indigenous Knowledge from Ibadan, Southwestern Nigeria. In: Proceedings of a National Workshop on the Potentials of the Star Apple in Nigeria (Eds.) pp: 25 - 33.

[3]. Adisa SA., 2000. Vitamin C, Protein and mineral contents of African Apple (Chrysophyllum albidum) IN: Proceedings of the 18th annual conference of NIST. (Eds.), pp $141-146$.

[4]. Amusa NA., Ashaye OA., Oladapo MO., 2003. Biodeterioration of the African Star apple (Chrysophyllum albidum) in storage and the effect on its food value. Afr. J. Biotech., 2: $56-59$.

[5]. Bada SO. (1997), Preliminary information on the ecology of Chrysophyllum albidum done in the West and Central Africa; In proceedings of a National Workshop on the potentials of Star Apple in Nigeria, pp $16-25$

[6]. Ganguly T, Sainis KB (2001). Inhibition of cellular immune response by Tylophora indica In experimental models. Phytomed. 8(5): 348-355.

[7]. Gopalakrishnan C, Shankaranarayan D, Kameswaran L, Natarajan S, (1979). Pharmacological investigations of tylophorine, the major alkaloid of Tylophora indica. Indian J. Med. Res. 69: 513-520.

[8]. Hugo WB, Russel AD. Pharmaceutical microbiology, 3rd edition. Blackwell Scientific Publication. $1983 ; 47$.

[9]. Idowu TO, Iwalewa EO, Aderogba MA, Akinpelu BA and Ogundaini AO 2006. Antinociceptive, Anti - inflammatory and Antioxidant activities of Eleagnine: an alkaloid isolated from seed cotyledon of C.albidum. Jour. Of Biological Sciences 6 (6): 1029 -1034 .

[10]. Okoli BJ and Okere OS (2010) Antimicrobial activity of the phytochemical constituents of Chrysophyllum albidum Plant. Jour.Of Research in Nat. Deve. Vol. 8 no 1. 